\title{
Superior Recovery by Pelletization of Landfilled Industry and Mining Related Fine and Small Size Iron Containing Waste
}

\author{
Sorina Gabriela Șerban, Imre Kiss
}

University Politehnica Timişoara, Department of Engineering \& Management, Faculty of Engineering Hunedoara, 5, Revolutiei, Hunedoara, Romania e-mails: sorina.serban@fih.upt.ro,imre.kiss@fih.upt.ro

\begin{abstract}
Over the last few decades, the steel industry has focused efforts on the improvement of by-product recovery, based on sustainable solutions. These activities have led the steel industry to save natural resources and to reduce its environmental impact. In fact, the by-product recovery is perceived as improving the environmental sustainability of the steel production by saving primary raw materials and costs related to by-products and waste landfilling. The iron- and steelmaking industry is also looking at residues from other industrial sectors such as mining and mineral processing. The objective is to develop viable practices, combining different mining and mineral processing wastes in high quality pellets and reducing environmental impacts and operating costs in steelmaking. Reuse these wastes allows for their beneficial application, whereas, recycling extracts resource ingredients or converts waste into valuable products in a long term perspective. Laboratory phase experiments carried out on the possibilities of valuing ferrous sludges and dusts, leads to the production of experimental by-products - pellets, usable as raw material in the steel industry in the steel production sector. Related to the recovery technologies of ferrous waste for the purpose of "greening" the industrial environment, our research has focused on identifying possibilities for the recovery of industrial iron containing, small size and powdery waste, which are landfilled, in very large quantities, in the Hunedoara area of Romania and beyond.
\end{abstract}

Keywords: raw materials; iron \& steelmaking industry; waste recovery; pellets/ pelletizing

\section{Introduction}

Waste has become a major problem for the various industrial sectors, especially the mining, mineral processing and metallurgical sectors [1-4]. Concepts like prevention, reuse, recycling, recovery, disposal and their ranking are on the order of the day in the management of the different streams of waste. For materials industry, the issue of waste management through recovery (recovery and 
recycling) is an environmental and economic priority [1-8]. Recovery shall include the collection, transport, storage, selection and processing of certain waste [5-12]. Waste contains substances generated by the industrial activity in which it is produced and the disposal of such waste from the productive cycle is carried out:

\section{- By appropriate recovery}

- By recovery and/or storage for recycling

— By stabilisation for storage in landfills

This waste can be reintroduced into a technological flow through internal and/or external recycling [5-12]. Finding economically and environmentally efficient solutions for technological flows in the materials industry must enable the superior recovery of waste. Small size and powdery ferrous waste can be reintroduced into the economic circuit of the steelmaking [8-24]. Thus, we can make by-products results from such industrial small size and powdery waste, from steelmaking and other industries such as mining and area of processing of minerals [8, 12-24].

During the iron- and steelmaking processes, several by-products are produced, such as slags, dusts, sludges and other residues [8-12]. Based on the iron- and steelmaking industry's reports, on average, for one ton of steel $200 \mathrm{~kg}$ (in the scrap-based steelmaking, mainly based on the electric arc furnace) and $400 \mathrm{~kg}$ (in the iron ore-based steelmaking, based on agglomerating-blast furnace-convertor) of by-products are produced [8-12].

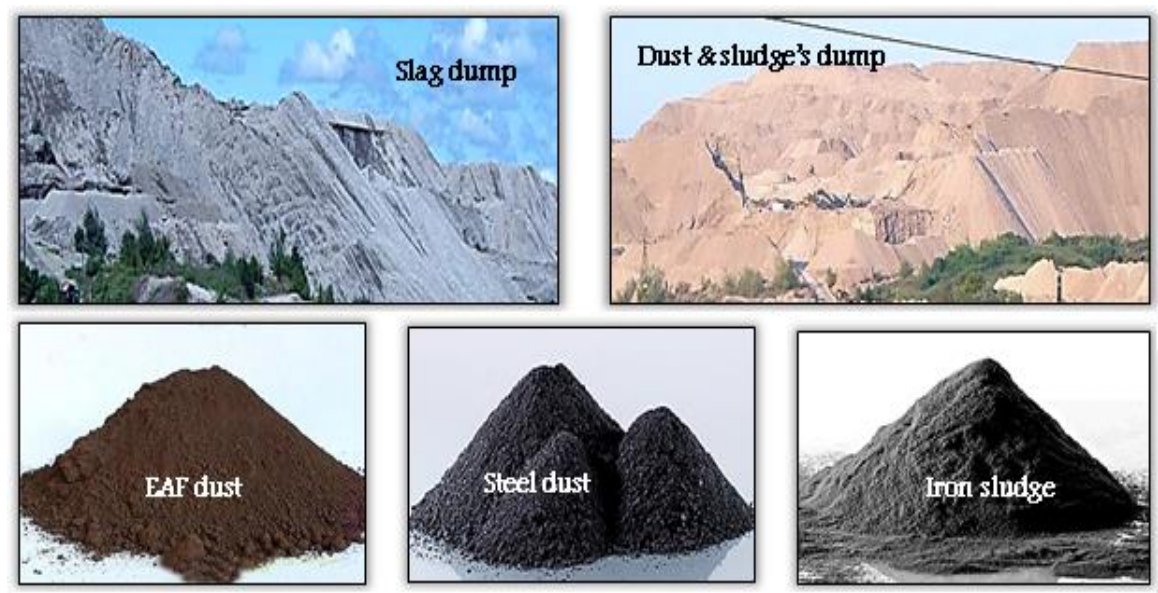

Figure 1

Slags, dusts, sludge and other residues

Dust and sludge (Figure 1) are mostly coming from the dust removal equipment, equipped with filters, that clean the gases and wastewater discharges from the various iron and steelmaking processes [8-12]. In particular, sludges derive from 
dust or fines in different steelmaking processes. All these residues - be they waste or by-products - contain a relevant fraction of iron and other metal oxides [8-12]. Blast furnace dust includes gas ash and gas slime, it mainly is made of iron oxide powder, coke powder and coal powder, together with appreciable amounts of $\mathrm{Si}$, $\mathrm{Al}, \mathrm{Ca}, \mathrm{Mg}$, etc. Producing one ton of iron generate about $15-50 \mathrm{~kg}$ furnace dust [8-12]. The dust and sludge generated from the electric arc furnace (EAF) contains important metallic elements, such as $\mathrm{Fe}, \mathrm{Zn}, \mathrm{Cr}, \mathrm{Pb}, \mathrm{Cd}$, etc. Producing one ton of steel generate about 10-25 kg dust [8-12].

Also, the mining and mineral processing sectors generates considerably amounts of waste materials that vary depending on their physical and chemical composition, the type of mining and the way the mineral is processed. These generally have very little economic value, making their exploitation not profitable. Though, mine tailings (Figure 2) may contain base transition metals, such as iron, copper, nickel and zinc, in relatively high concentrations [8-12].

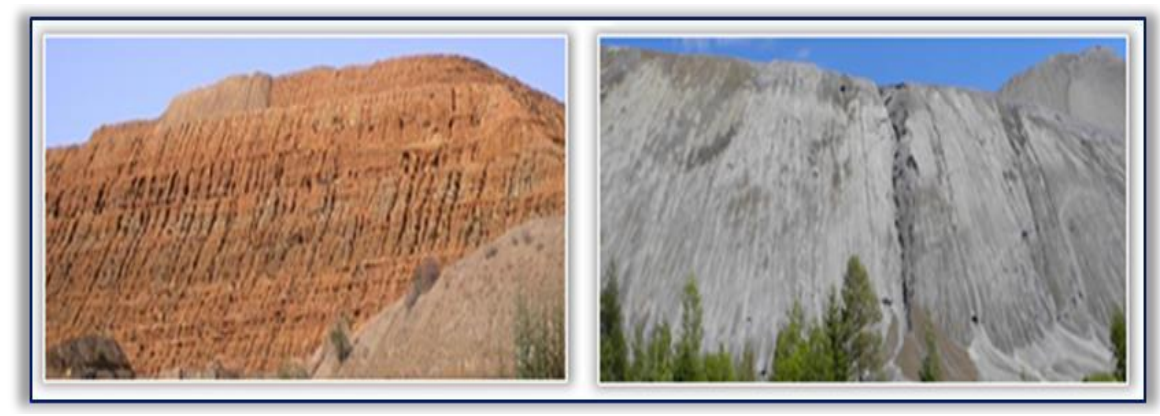

Figure 2

Mine tailings

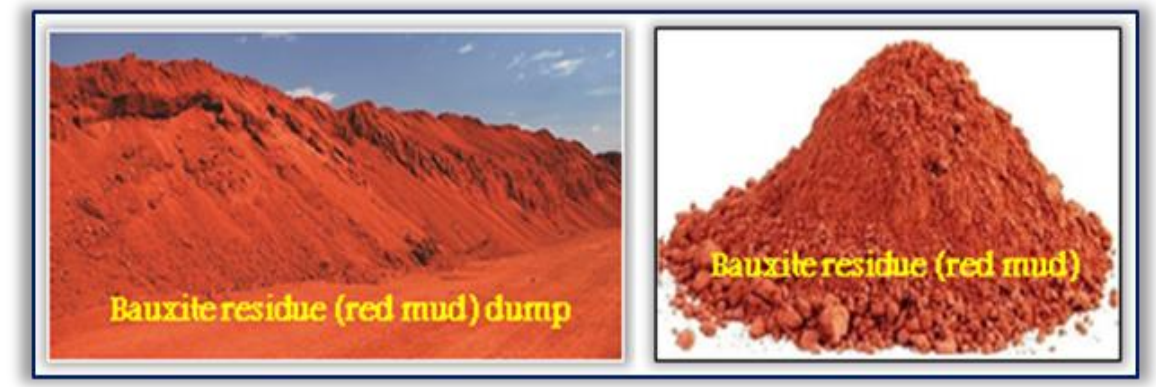

Figure 3

Bauxite residue (red mud)

For each ton of aluminum produced, around 1-2 tons of bauxite residue (red mud, Figure 3) are also produced, creating a massive amount of industrial waste to manage [8] [12] [15-18]. This residue, represents a significant challenge to the 
industry due to its highly caustic nature and the significant quantities in which it is produced. While red mud composition varies based on the source of bauxite and other variables, it is comprised mainly of various oxides (the high iron oxide content found in the residue is what gives red mud its name). As one of the largest industrial by-products, finding an alternative use for red mud could turn an industry problem into a potential benefit and reducing environmental risks. Despite the significant waste challenge that this industrial by-product presents, red mud is also a waste, rich in resources, containing a variety of materials that could be useful, if recovered [8] [12] [15-24]. Bauxite residue is mainly composed of iron oxides, titanium oxide, silicon oxide and un-dissolved alumina together with a wide range of other oxides which will vary according to the country of origin of the bauxite. Therefore, the ability to recover such materials becomes increasingly attractive [8] [12] [15-18] [24].

Of all the waste generated in the industry, the small size and powdery waste has caused problems in recovery due to unsatisfactory granulometric composition as well as due to its high heavy metal content $(\mathrm{Cd}, \mathrm{Cr}, \mathrm{Pb}, \mathrm{Ni}, \mathrm{Cu}, \mathrm{Mn}$ and $\mathrm{Zn})$ [8] [12]. Powdery ferrous waste comes mostly from steelmaking activities and generally results from the various treatment of exhaust gases and waste water, either in dry form (from dry treatment plants) or below form of wet dust or sludge from wet treatment plants. The materials industry results in various wastes, such as dust, metal powders, metal oxides $\left(\mathrm{Fe}_{2} \mathrm{O}_{3}, \mathrm{Al}_{2} \mathrm{O}_{3}, \mathrm{TiO}_{2}, \mathrm{ZnO}, \mathrm{PbO}, \mathrm{MgO}, \mathrm{MnO}\right.$, $\mathrm{Cr}_{2} \mathrm{O}_{3}$, etc.) or non-metallic oxides $\left(\mathrm{SiO}_{2}, \mathrm{P}_{2} \mathrm{O}_{5}, \mathrm{CaO}\right.$, coal, etc.). Small size and powdery ferrous wastes are present, in all cases, in the form of oxides [8] [12].

These residues are increasingly being reprocessed internally, as briquettes and pellets, at least at the integrated steelmaking route [5-8] [12]. In this sense, the recycling of converter dusts via briquetting and returning to the basic oxygen furnace is well established technique. Recycling of steel dusts via pelletizing and returning to the electric arc furnace is also a viable method [8] [12] [15-18]. The internal recycling of blast furnace dust and agglomerating dust in the pelletization process has been developed and implemented, taking into account achieving a high quality of pellets and reducing environmental impacts and operating costs in steelmaking [8] [12] [15-24].

On the other hand, the residue which are not internally recycled can be externally sold and used by other sectors, in different applications [8] [12]. Or, they were disposed in landfill, although, in the past years, significant improvement has been realized reducing the level of materials sent to landfills [8] [12].

Therefore, iron- and steelmaking residues (slags, dusts or sludges) and the mining and related mineral processing wastes (mainly sludges) must be revalorized either within the steelmaking process or as industrial by-product as raw materials source via industrial symbiosis or internal cascading use, for several reasons [8] [12-18]:

- The high content of iron and metal oxides makes residue valuable raw material for new steel charge. 
- The chemical and physical properties allow reuse of residues and by-products of steel plant in other industries or contexts.

- The tightening environmental legislation makes the landfill disposal of wastes more expensive.

Pelletizing is a process of particle size enlargement used to small size and powdery ferrous materials into larger, cohesive particles, named pellets [12] [1518]. Employed throughout a wide range of industries, pelletizing is capable of transforming dusty or difficult to handle materials from iron- and steel industry and the mining and related mineral processing sectors into a more manageable form, even offering a number of technological, economic or environmental benefits as a result such [8] [12]:

- Dust suppression and elimination of dust and powdery ferrous wastes

- Mitigation of dust loss

- Reducing the wastes from landfills

- Conversion of a waste material to a marketable product

— Increased porosity, density and melting abilities, etc.

\section{Materials}

We used wastes resulted from ferrous industry (steel dust, agglomerating-furnace dust) and mining and mineral processing sectors (red mud, anti-corrosive/ galvanic sludge) [12] [15-18] [24]. In addition, in the pellets recipes, graphite is used as the reducing agent, respectively bentonite and lime are used as binders (Figure 4). The chemical composition of the materials in the Table 1-4 are presented.

Table 1

Chemical composition of the agglomerating / blast furnace slag - Hunedoara, $(\%)[12,24]$

\begin{tabular}{|l|l|l|l|l|l|l|l|l|}
\hline $\mathrm{SiO}_{2}$ & $\mathrm{CaO}$ & $\mathrm{MgO}$ & $\mathrm{Al}_{2} \mathrm{O}_{3}$ & $\mathrm{MnO}$ & $\mathrm{FeO}$ & $\mathrm{Fe}_{2} \mathrm{O}_{3}$ & $\mathrm{ZnO}$ & Other oxides \\
\hline 14.06 & 10.01 & 2.57 & 6.44 & 0.96 & 12.36 & 40.71 & 4.79 & 10.9 \\
\hline
\end{tabular}

Table 2

Chemical composition of the steel dust (electric arc furnace) - Hunedoara, $(\%)[12,24]$

\begin{tabular}{|l|l|l|l|l|l|l|l|}
\hline $\mathrm{Fe}_{2} \mathrm{O}_{3}$ & $\mathrm{FeO}$ & $\mathrm{MnO}$ & $\mathrm{SiO}_{2}$ & $\mathrm{CaO}$ & $\mathrm{MgO}$ & $\mathrm{Al}_{2} \mathrm{O}_{3}$ & Other oxides \\
\hline 73.37 & 2.98 & 4.80 & 3.49 & 5.11 & 2.34 & 1.07 & 4.92 \\
\hline
\end{tabular}




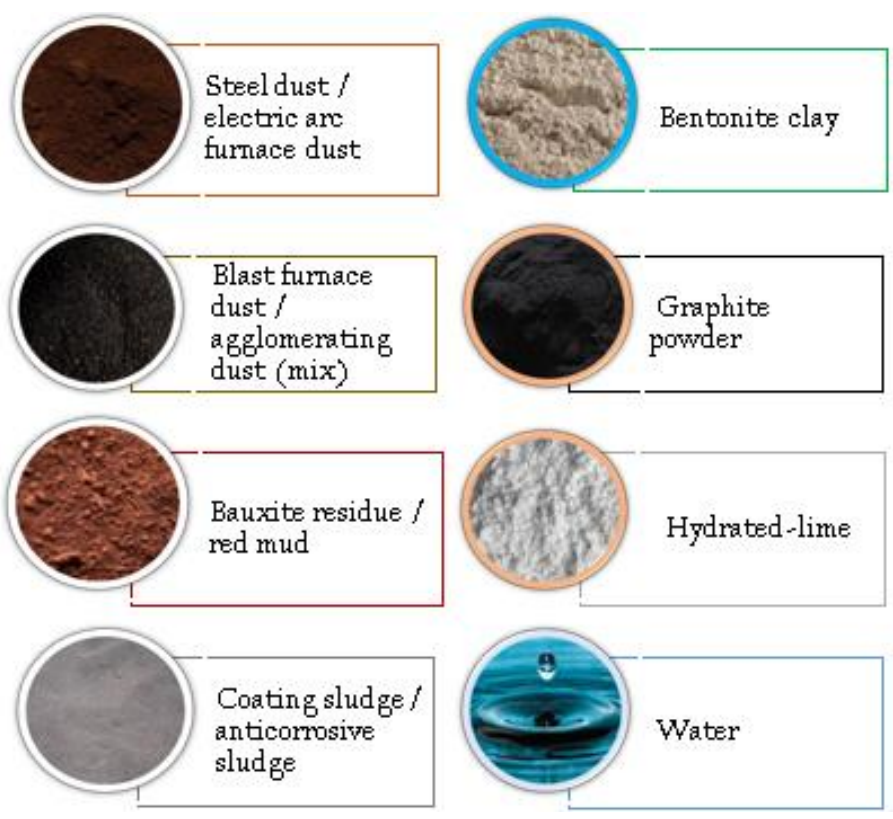

Figure 4

Materials for the pellets recipes

Table 3

Chemical composition of the bauxite residue (red mud) - Oradea, $(\%)$ [12, 24]

\begin{tabular}{|l|l|l|l|l|l|l|l|l|}
\hline $\mathrm{Fe}_{2} \mathrm{O}_{3}$ & $\mathrm{Al}_{2} \mathrm{O}_{3}$ & $\mathrm{CaO}$ & $\mathrm{SiO}_{2}$ & $\mathrm{TiO}_{2}$ & $\mathrm{Na}_{2} \mathrm{O}$ & $\mathrm{Cr}_{2} \mathrm{O}_{3}$ & $\mathrm{ZnO}$ & Other oxides \\
\hline 36.63 & 27.22 & 16.35 & 8.31 & 5.12 & 3.77 & 0.250 & 0.112 & 1.10 \\
\hline
\end{tabular}

Table 4

Chemical composition of the anti-corrosive/ galvanically mud - Oradea, $(\%)[12,24]$

\begin{tabular}{|l|l|l|l|l|l|l|l|l|l|}
\hline $\mathrm{ZnO}$ & $\mathrm{Fe}_{2} \mathrm{O}_{3}$ & $\mathrm{Na}_{2} \mathrm{O}$ & $\mathrm{NiO}$ & $\mathrm{P}_{2} \mathrm{O}_{5}$ & $\mathrm{SiO}_{2}$ & $\mathrm{Al}_{2} \mathrm{O}_{3}$ & $\mathrm{CaO}$ & $\mathrm{Cr}_{2} \mathrm{O}_{3}$ & Other oxides \\
\hline 24.43 & 21.59 & 12.33 & 7.73 & 5.56 & 5.44 & 3.52 & 1.72 & 1.15 & 8.02 \\
\hline
\end{tabular}

Table 5

Basicity of the recipe's components [12, 24]

\begin{tabular}{|l|l|l|l|l|}
\hline Components & $\begin{array}{l}\text { Agglomerating / } \\
\text { blast furnace } \\
\text { slag - } \\
\text { Hunedoara }\end{array}$ & $\begin{array}{l}\text { Steel dust (electric } \\
\text { arc furnace) - } \\
\text { Hunedoara }\end{array}$ & $\begin{array}{l}\text { Bauxite } \\
\text { residue (red } \\
\text { mud) - } \\
\text { Oradea }\end{array}$ & $\begin{array}{l}\text { Anti-corrosive/ } \\
\text { galvanically } \\
\text { mud - Oradea }\end{array}$ \\
\hline Basicity, B & 0.7119 & 1.4641 & 1.9675 & 0.3161 \\
\hline
\end{tabular}

Basicity defines the chemical composition and the metallurgical properties of such materials, being the ratio (in percent of weight) of basic and acid oxides in iron ore materials and in blast-furnace and steel dust and/or slags. In the simplest case, 
basicity is defined as the ratio of $\mathrm{CaO}$ to $\mathrm{SiO}_{2}$ or of the total of $\mathrm{Cao}$ and $\mathrm{MgO}$ to that of $\mathrm{Al}_{2} \mathrm{O}_{3}$ and $\mathrm{SiO}_{2}[12,15-18,24]$. The basicity of the recipe's components in the Table 5 is presented.

\section{Research Methodology}

The experimental equipment used for pelletizing belongs to the Laboratory of Materials Processing, in Faculty of Engineering Hunedoara [12-24]. The disk pelletizer is shown in the Figure 5 [12-24].

A certain amount of waste is introduced into the peletizer and water is added for damping, and bentonite is used as a binder. The pelletization is continued until the pellet is obtained with a diameter of $10-15 \mathrm{~mm}$. From each load, several raw pellets are retained to determine compression resistance, the rest being burned in electric furnace, and after cooling the physico-mechanical characteristics will be determined.

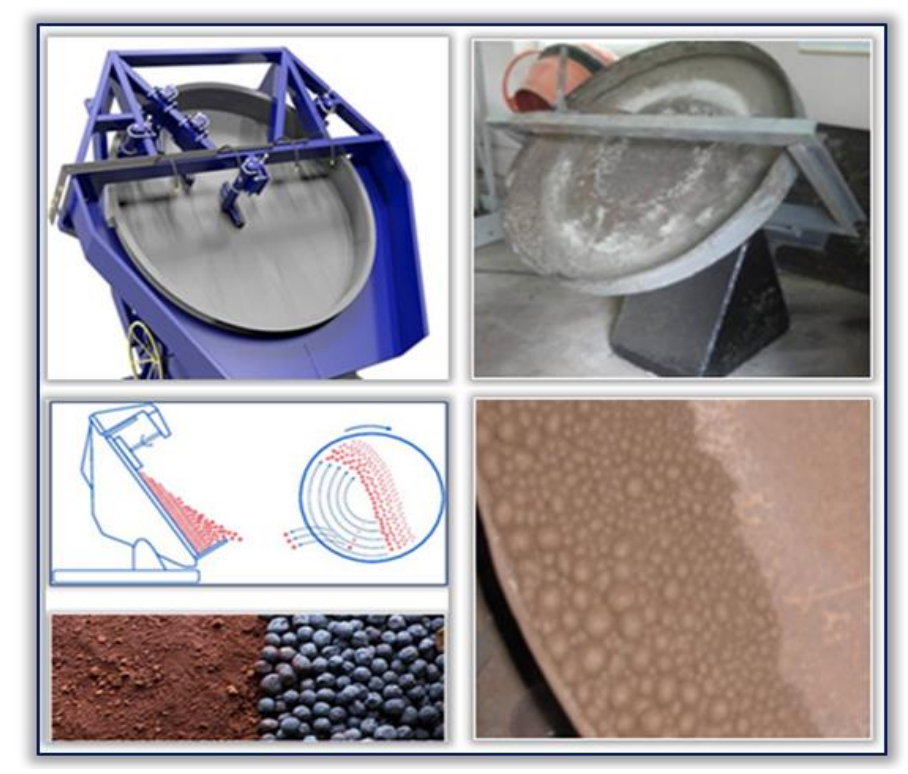

Figure 5

Pelletizing equipment and process with disk pelletizer [12, 15-18, 24]

The production of ferrous pellets from small size and powdery ferrous content materials to finished by-product can differ based on a variety of factors, the process being a more operator dependent process than that of pressure agglomeration [8] [12]. Variables that affect the pelletizing process, as well as the 
quality of the end by-products (i.e. pellets), vary depending on the raw materials and the process employed. In general, however, the following parameters play an influential role in the pelletizing process [8] [12] [24]:

- Ferrous materials characteristics (chemical composition, particle size distribution, consistency, moisture content)

- Additive and binder characteristics (particle size distribution, moisture content)

- Proportionating rate and mixing the components (ferrous material feed rate, binder feed rate, additive feed rate, water quantity)

- Pelletiser's characteristics (rotational speed, disc angle and inclination)

- Operating characteristics (temperature, retention time)

- Procurement and receiving raw material related factors (raw material feed location, transport)

The "green" pellets produced on a disc pelletizer into the balling process (pelletizing) are not uniform in diameter [12] [15-18] [24]. A significant portion of the discharge (about 70\%) is smaller than target size and must be returned to the pelletizer after screening. The pelletizing operation, however, is stable for uniform raw material conditions (chemical composition, particle size, moisture content, etc.), being easily adjustable for varying small size and powdery ferrous raw material conditions by changing the rotational speed, disc angle and inclination, feed rate and moisture addition [12] [15-18] [24].

The hardening of the pellets is produced by burning, in electric furnace (Figure 6), following a proper treatment diagram (heating - maintenance - cooling), established on the basis of its own experiments (heating at $1150^{\circ} \mathrm{C}$, for 2 hours, maintenance 30 minutes and cooling in the air) [12] [24]. After hardening, qualitative characteristics (chemical composition, dimensional analysis) and a mechanical characteristic (compression resistance of burned pellets) were determined in our laboratories [12] [15-18] [24].

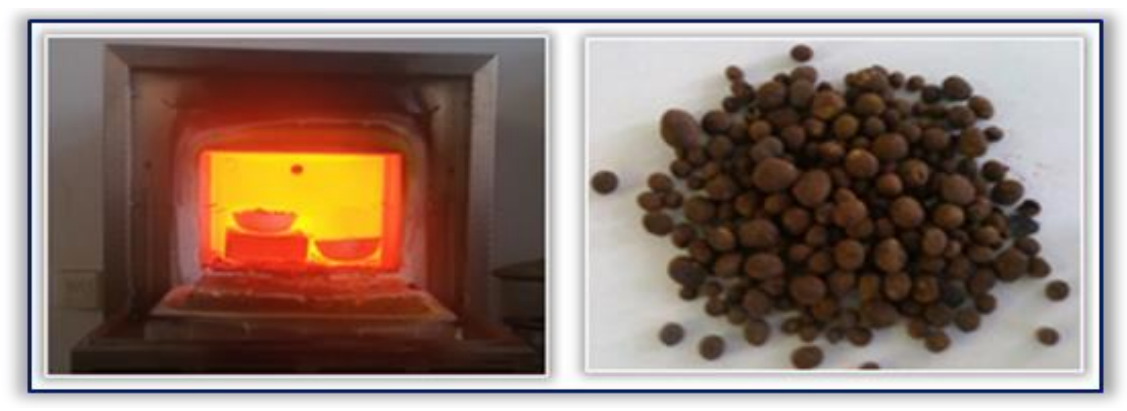

Figure 6

Hardening of the pellets [12, 24] 


\section{Results}

In our research, laboratory tests were carried out on the possibilities of recovery of powdery ferrous waste in the form of pellets. There were made pellets after 6 laboratory recipes, in 6 technological variants. The recipes compositions and their percentile participation for the pelletizing charges in Table 6 are presented. In our views came the small size wastes that finally gave compositions of the pellets with high content of $\mathrm{Fe}_{2} \mathrm{O}_{3}$ (33-43\%), but also appreciable quantities of $\mathrm{SiO}_{2}(10-17 \%)$, $\mathrm{Al}_{2} \mathrm{O}_{3}$ (2-8\%), $\mathrm{ZnO}$ (5-16\%) and $\mathrm{CaO}$ (7-12\%), respective steel dust, agglomeration-furnace dust, red mud / bauxide residue and anti-corrosive sludge (Table 7).

The raw materials were dried, classified and then processed. The raw materials were pelletized with the help of the pelletization plant (Figure 5), taking into account both the amount of material used and the amount of water needed to obtain the end by-products (i.e. pellets). Bentonite was used as a binder. After hardening (burning), for the determination of compression resistance, $15 \mathrm{~mm}$ diameter pellets were selected, the results being presented in Table 8 .

Table 6

The recipes compositions and their percentile participation [12, 24]

\begin{tabular}{|l|l|l|l|l|l|l|l|}
\hline No. & Used wastes & R\#1 & R\#2 & R\#3 & R\#4 & R\#5 & R\#6 \\
\hline 1. & Steel dust & 72 & - & 72 & - & 70 & - \\
\hline 2. & Agglomerating-furnace dust & - & 72 & - & 72 & - & 70 \\
\hline 3. & Bauxite residue / red mud & 12 & 12 & 24 & - & - & 24 \\
\hline 4. & Anti-corrosive mud & 12 & 12 & - & 24 & 24 & - \\
\hline 5. & Graphite & - & - & - & - & 1 & 1 \\
\hline 6. & Bentonite & 4 & 4 & 4 & 4 & 3 & 3 \\
\hline 7. & Lime & - & - & - & - & 2 & 2 \\
\hline
\end{tabular}

Table 7

Chemical compositions of pellets [12]

\begin{tabular}{|l|l|l|l|l|l|l|}
\hline \multirow{2}{*}{ Name of oxides } & \multicolumn{5}{l}{ No. of experiments } \\
\cline { 2 - 7 } & R\#1 & R\#2 & R\#3 & R\#4 & R\#5 & R\#6 \\
\hline $\mathrm{Fe}_{2} \mathrm{O}_{3}$ & 43.15 & 33.57 & 38.42 & 40.02 & 34.73 & 36.02 \\
\hline $\mathrm{SiO}_{2}$ & 17.28 & 16.84 & 16.52 & 18.68 & 11.15 & 10.37 \\
\hline $\mathrm{ZnO}$ & 9.13 & 9.47 & 8.76 & 5.81 & 16.99 & 16.73 \\
\hline $\mathrm{CaO}$ & 11.56 & 11.08 & 10.96 & 9.56 & 7.57 & 7.44 \\
\hline $\mathrm{Al}_{2} \mathrm{O}_{3}$ & 8.14 & 8.33 & 7.54 & 7.26 & 2.80 & 2.43 \\
\hline $\mathrm{Na}_{2} \mathrm{O}$ & 4.13 & 4.20 & 5.32 & 6.12 & 7.33 & 7.67 \\
\hline $\mathrm{MgO}$ & 1.15 & 2.08 & 1.89 & 2.37 & 2.60 & 2.56 \\
\hline $\mathrm{MnO}$ & 1.04 & 1.33 & 1.62 & 1.13 & 2.20 & 2.14 \\
\hline $\mathrm{P}_{2} \mathrm{O}_{5}$ & 1.34 & 1.45 & 1.28 & 3.11 & 2.41 & 2.53 \\
\hline Other oxides & 3.08 & 11.65 & 7.69 & 5.9 & 12.0 & 12.0 \\
\hline
\end{tabular}


Table 8

Compression resistance of the resultant pellets $[12,24]$

\begin{tabular}{|l|l|l|l|l|l|l|}
\hline Recipe no. & R\#1 & R\#2 & R\#3 & R\#4 & R\#5 & R\#6 \\
\hline $\begin{array}{l}\text { Compression } \\
\text { resistance of pellets } \\
\text { [daN/pellet] }\end{array}$ & 194 & 179.5 & 205 & 210.5 & 178 & 178.5 \\
\hline
\end{tabular}

\section{Discussion}

Our analysis on the study of the influence of pellet's chemical composition on compression resistance are graphically represented in Figures 7-15, based on the results obtained in our laboratory experiments. The following technological discussions are required:

- In the diagram presented in Figure $7\left[\mathrm{Rc}=\mathrm{f}\left(\mathrm{Al}_{2} \mathrm{O}_{3}, \mathrm{CaO} / \mathrm{SiO}_{2}\right)\right]$ it is noted that the compression resistance increases with the increase in the content of $\mathrm{Al}_{2} \mathrm{O}_{3}$. At the same time as the increase in the basicity $\left(\mathrm{CaO} / \mathrm{SiO}_{2}\right.$ ratio), higher values being obtained for an $\mathrm{Al}_{2} \mathrm{O}_{3}$ content greater than $8-10 \%$, even at low basicity values $(0.7-0.8)$

- In the diagram presented in Figure $8\left[\mathrm{Rc}=\mathrm{f}\left(\mathrm{ZnO}, \mathrm{CaO} / \mathrm{SiO}_{2}\right)\right]$ it is noted that the compression resistance decreases with the increase in $\mathrm{ZnO}$ content, while increasing the basicity, higher values being obtained for a $\mathrm{ZnO}$ content greater than $6-9 \%$, even at low basicity values (over 0.7 )

- In the diagram presented in Figure $9\left[\mathrm{Rc}=\mathrm{f}\left(\mathrm{Al}_{2} \mathrm{O}_{3}, \mathrm{Fe}_{2} \mathrm{O}_{3}\right)\right]$ it is noted that the compression resistance increases with the increase in the content of $\mathrm{Al}_{2} \mathrm{O}_{3}$, reaching values of about $200 \mathrm{daN} /$ pellet at values of over $9.5 \%$, even at low values of $\mathrm{Fe}_{2} \mathrm{O}_{3}$, framed in the range of $1-5 \%$

- In the diagram presented in Figure $10\left[\mathrm{Rc}=\mathrm{f}\left(\mathrm{Al}_{2} \mathrm{O}_{3}, \mathrm{SiO}_{2}\right)\right]$ it is noted that the compression resistance increases with the increase in the content of $\mathrm{Al}_{2} \mathrm{O}_{3}$, reaching acceptable values above 7-8\%, compared to an increase in $\mathrm{SiO}_{2}$ at values of more than $18 \%$

- In the diagram presented in Figure $11\left[\mathrm{Rc}=\mathrm{f}\left(\mathrm{Al}_{2} \mathrm{O}_{3}, \mathrm{ZnO}\right)\right]$ it is noted that the compression resistance has values of over $200 \mathrm{daN} /$ pellet at over 7-8\% $\mathrm{Al}_{2} \mathrm{O}_{3}$ and increases with the increase in $\mathrm{ZnO}$ content (over 15\%)

- In the diagram presented in Figure $12\left[\mathrm{Rc}=\mathrm{f}\left(\mathrm{Al}_{2} \mathrm{O}_{3}, \mathrm{CaO}\right)\right]$ it is noted that the compression resistance increases with increase in $\mathrm{CaO}$ content (over 9\%), in correlation with the provision of content of more than $6 \% \mathrm{Al}_{2} \mathrm{O}_{3}$

- In the diagram presented in Figure $13\left[\mathrm{Rc}=\mathrm{f}\left(\mathrm{Fe}_{2} \mathrm{O}_{3}, \mathrm{CaO}\right)\right]$ it is noted that the compression resistance increases with the increase of more than $35 \%$ of the 
$\mathrm{Fe}_{2} \mathrm{O}_{3}$ component, correlated with contents of more than $8 \% \mathrm{CaO}$, but decreases with contents of about $40 \% \mathrm{Fe}_{2} \mathrm{O}_{3}$ and over $10-10.5 \% \mathrm{CaO}$

- In the diagram presented in Figure $14\left[\mathrm{Rc}=\mathrm{f}\left(\mathrm{SiO}_{2}, \mathrm{CaO}\right)\right]$ it is noted that high values of compression resistance are obtained at over $8-9 \% \mathrm{CaO}$ and $12 \%$ $\mathrm{SiO}_{2}$, the trend being increasing with the increase in quantities of these components

- In the diagram presented in Figure $15\left[\mathrm{Rc}=\mathrm{f}\left(\mathrm{SiO}_{2}, \mathrm{Fe}_{2} \mathrm{O}_{3}\right)\right]$ it is noted that high compression resistance results are reached above $16 \% \mathrm{SiO}_{2}$ and $37 \%$ $\mathrm{Fe}_{2} \mathrm{O}_{3}$. Good values are also obtained at lower values of $\mathrm{SiO}_{2}$ content $(8-16 \%)$, but with increase in $\mathrm{Fe}_{2} \mathrm{O}_{3}$ content (over 37\%)

Based on the results obtained in our laboratory experiments, the followings are observed:

- The increase in the content of $\mathrm{CaO}$ and $\mathrm{Al}_{2} \mathrm{O}_{3}$ ensures an increase of the compression resistance, based on the binding capacity of these oxides, both acting as a binder of fine and small size particles. In order to have high values for compression resistance (over 160-180 daN/pellet) it is advisable to place the values for oxides only in the determined range.

- Concerning the $\mathrm{SiO}_{2}$ content, although it has a positive influence on compression resistance, as a result of the reduction of the superior iron oxide to $\mathrm{FeO}$ and the formation of iron silicate, a component that ensures the sintering of particles, it is desirable to have poor $\mathrm{SiO}_{2}$ content, concomitantly with $\mathrm{Fe}_{2} \mathrm{O}_{3}$ as high as possible, in order to have the greatest economic value of the obtained by-product (i.e. pellets).

- From the point of view of the content of $\mathrm{CaO}$ and $\mathrm{Fe}_{2} \mathrm{O}_{3}$ it is appropriate to find contents of these oxides (in the field indicated by the graphs) so as not to form brittle calcium ferrites. 


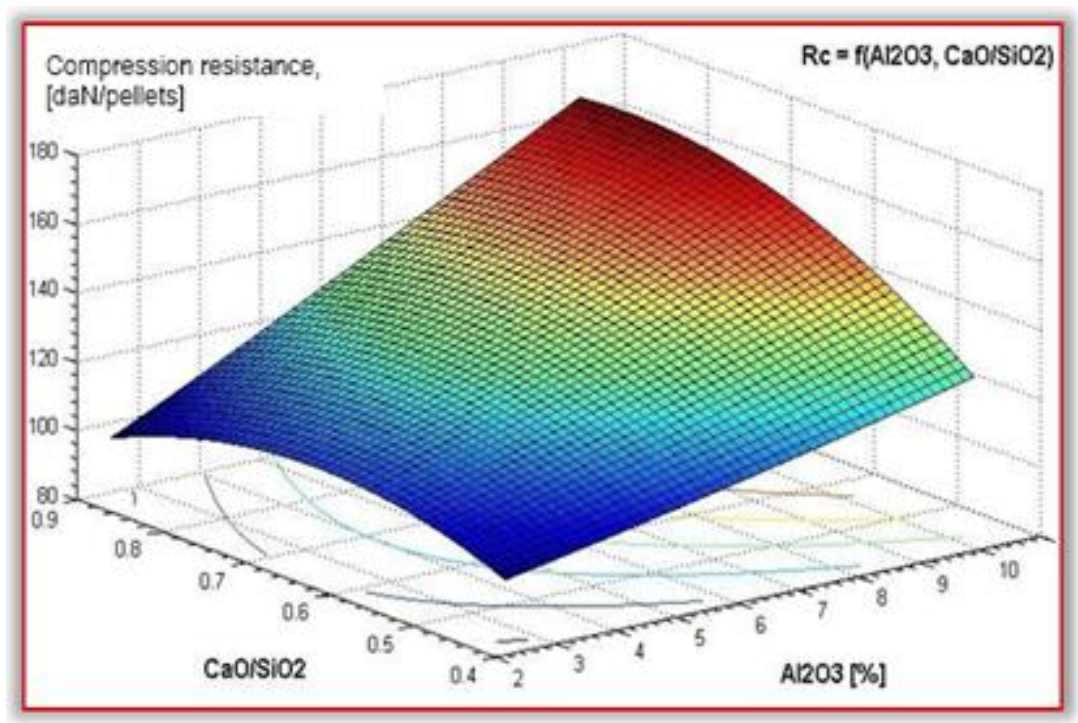

(a) spatial representation

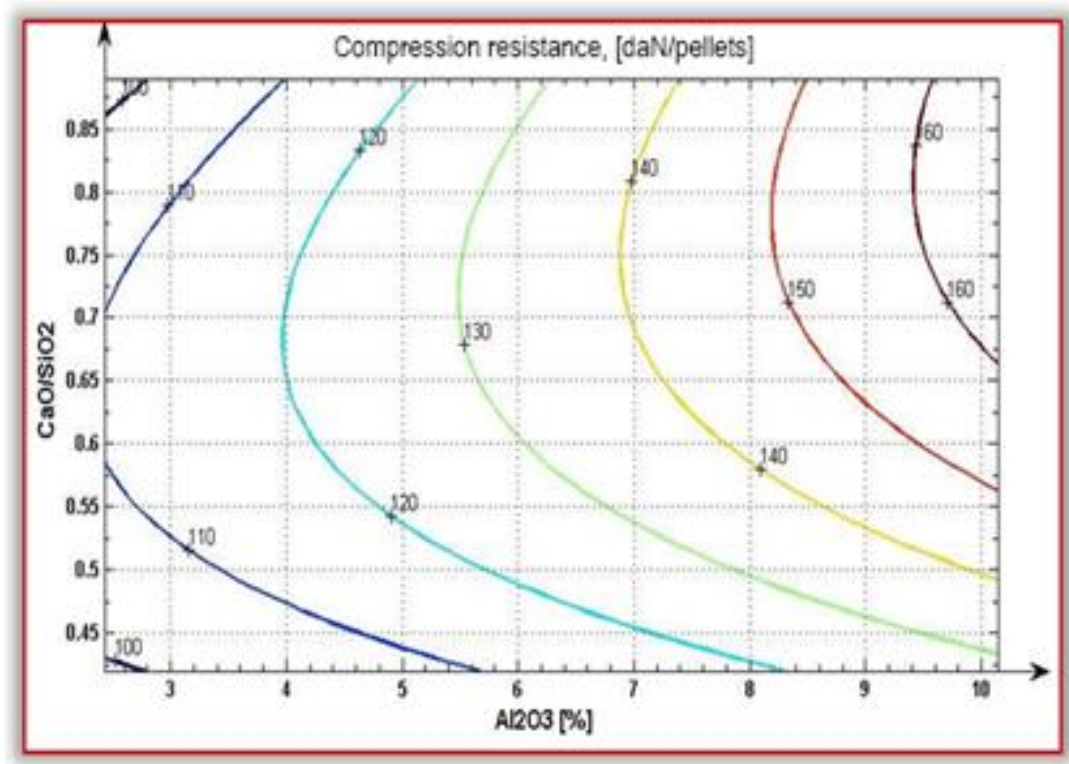

(b) horizontal projection level curves / correlation chart

Figure 7

Compression resistance of burned pellets according to the proportion of $\mathrm{Al} 2 \mathrm{O} 3$ and basicity (expressed by $\mathrm{CaO} / \mathrm{SiO}_{2}$ ratio) 


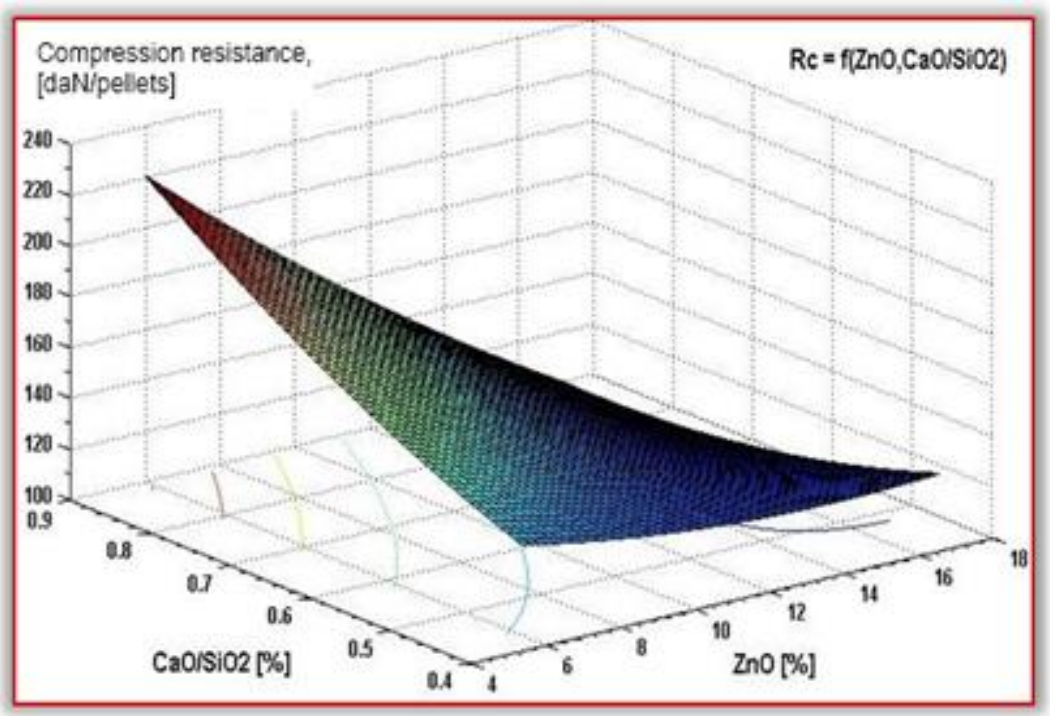

(a) spatial representation

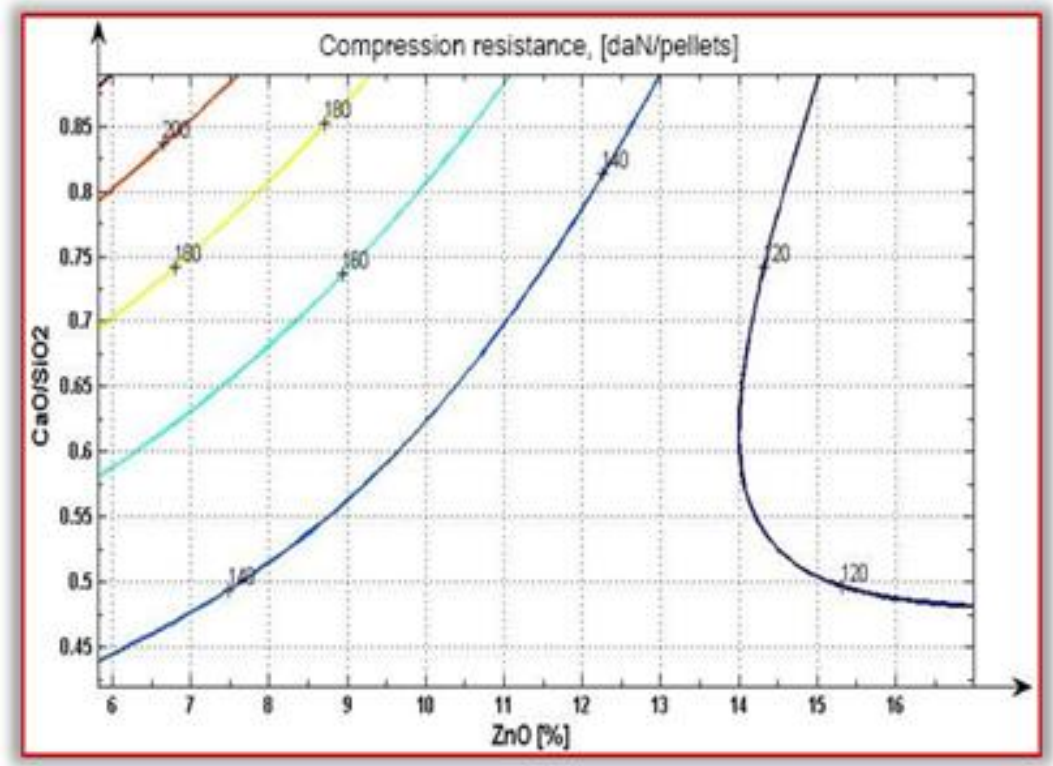

(b) horizontal projection level curves / correlation chart

Figure 8

Compression resistance of burned pellets according to the proportion of $\mathrm{ZnO}$ and basicity (expressed by $\mathrm{CaO} / \mathrm{SiO}_{2}$ ratio) 


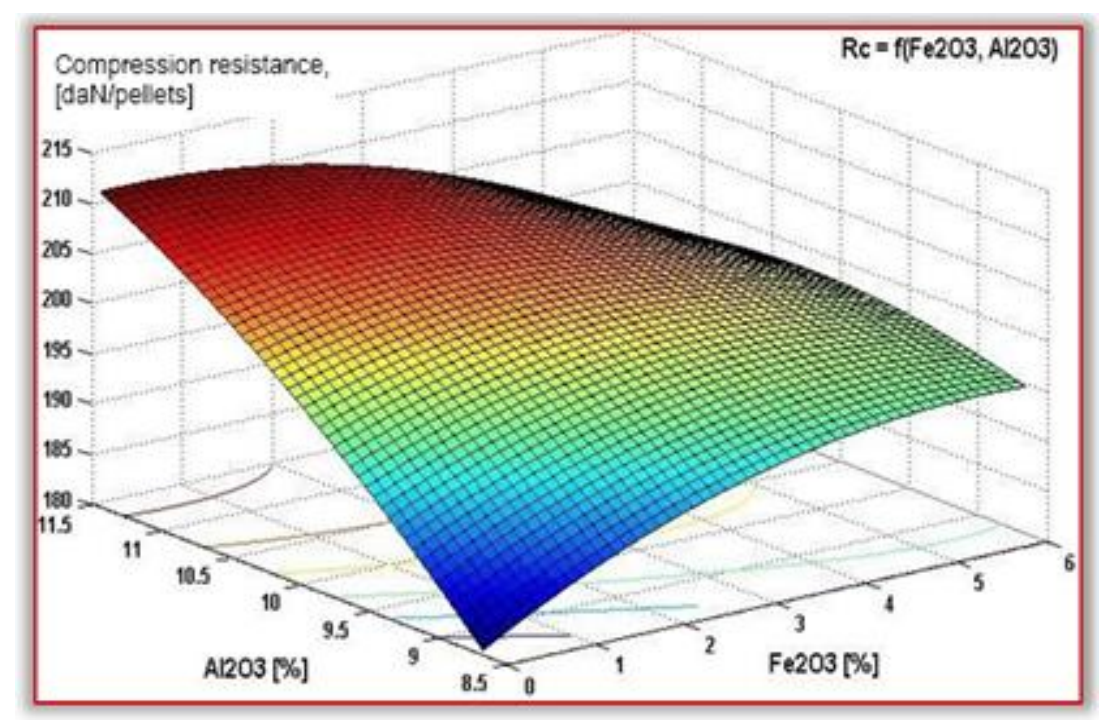

(a) spatial representation

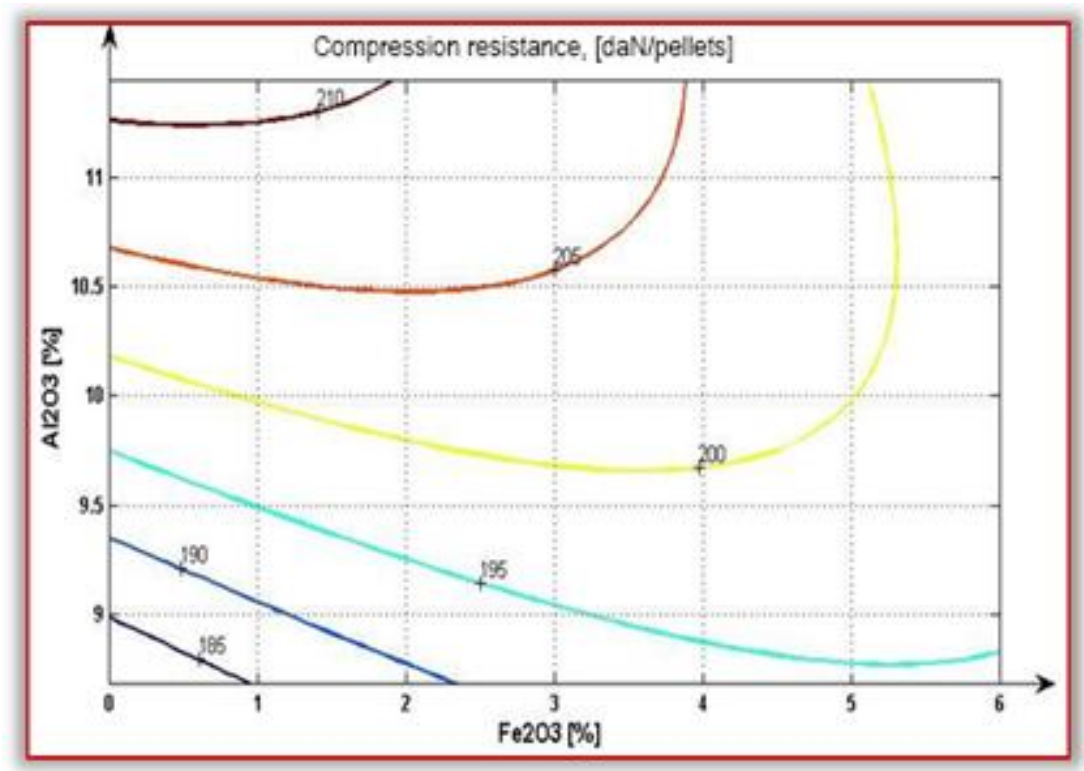

(b) horizontal projection level curves / correlation chart

Figure 9

Compression resistance of burned pellets according to the proportion of $\mathrm{Al}_{2} \mathrm{O}_{3}$ and $\mathrm{Fe}_{2} \mathrm{O}_{3}$ 


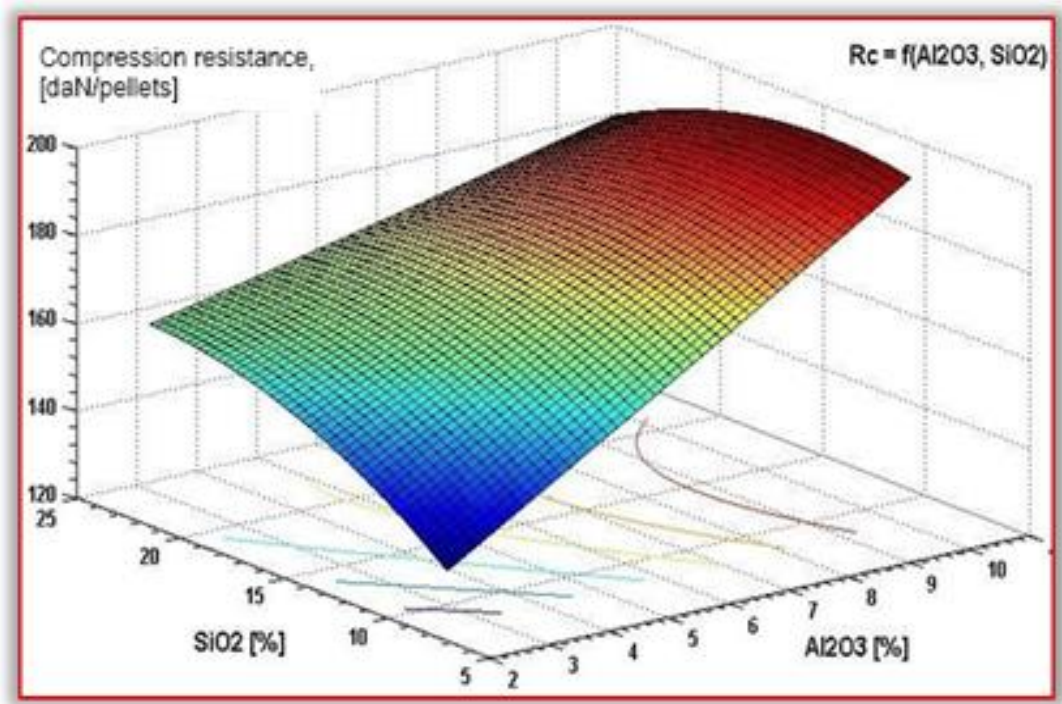

(a) spatial representation

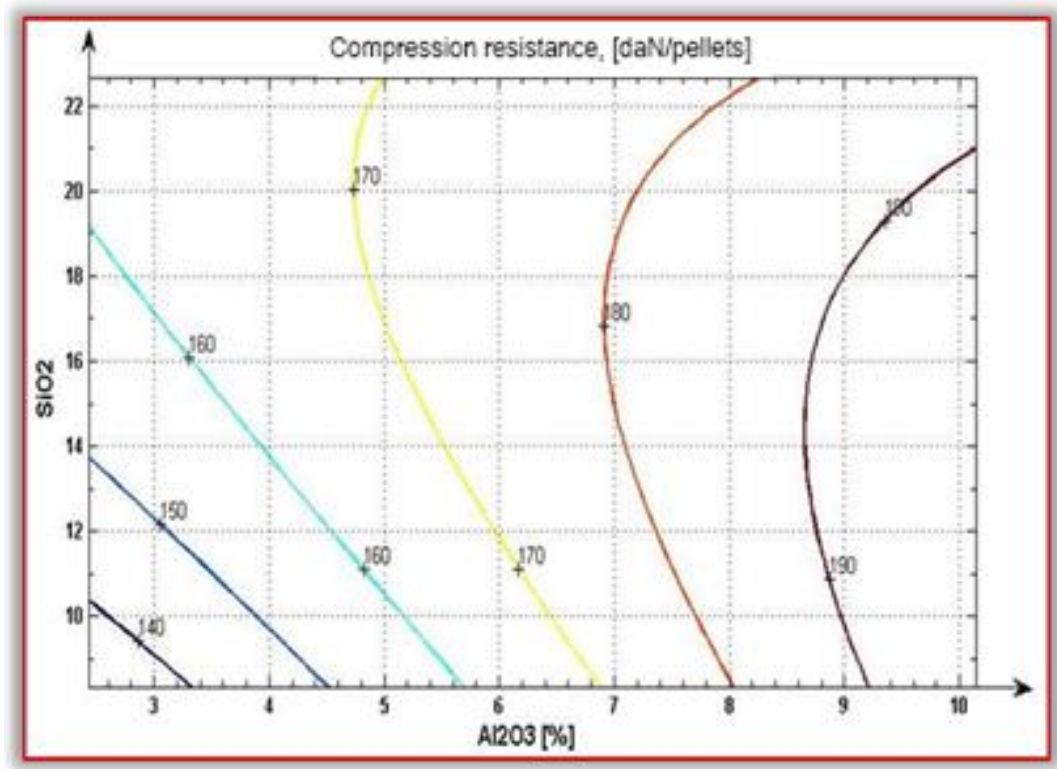

(b) horizontal projection level curves / correlation chart

Figure 10

Compression resistance of burned pellets according to the proportion of $\mathrm{Al}_{2} \mathrm{O}_{3}$ and $\mathrm{SiO}_{2}$ 


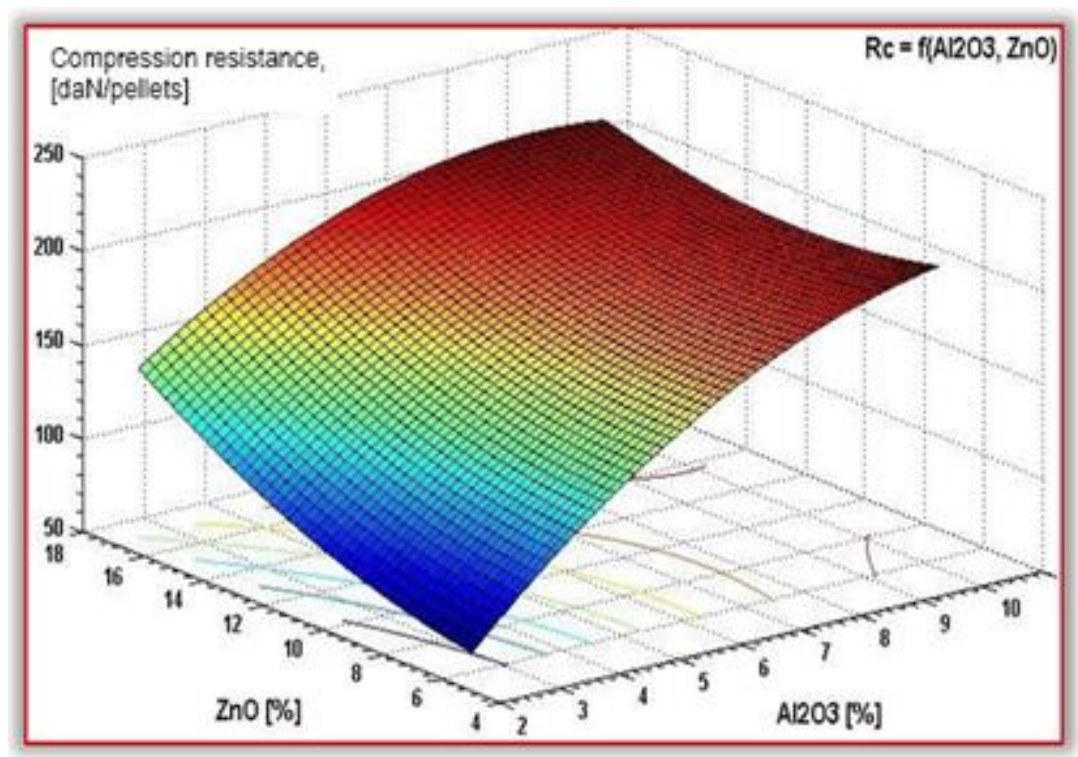

(a) spatial representation

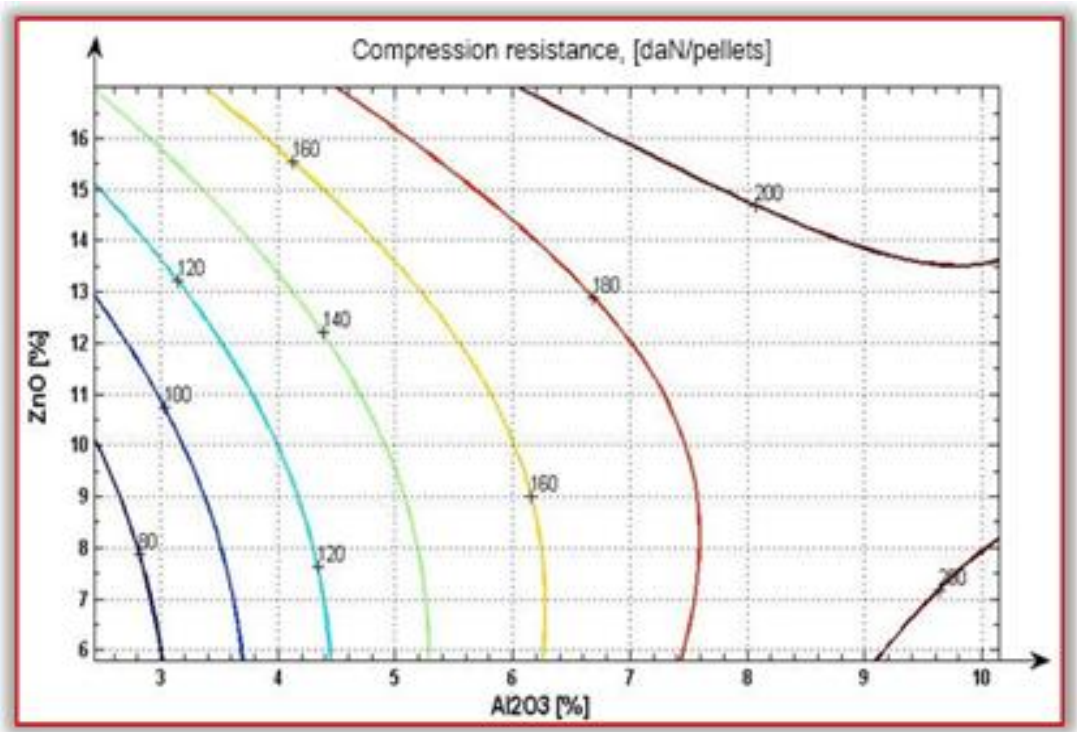

(b) horizontal projection level curves / correlation chart

Figure 11

Compression resistance of burned pellets according to the proportion of $\mathrm{Al}_{2} \mathrm{O}_{3}$ and $\mathrm{ZnO}$ 


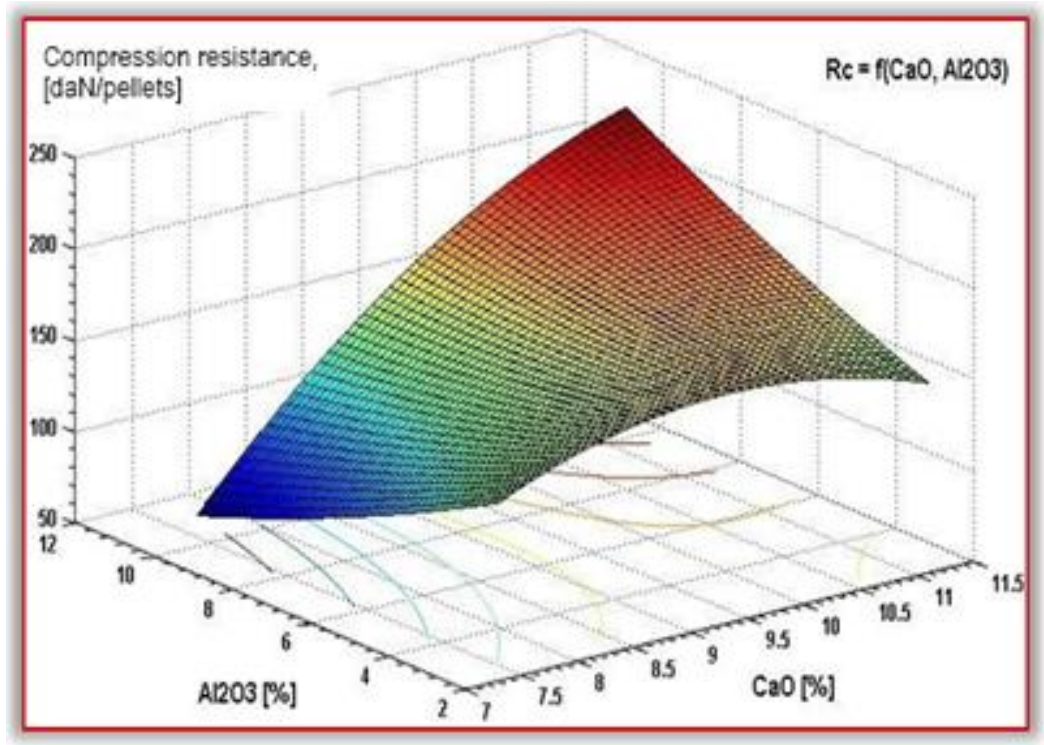

(a) spatial representation

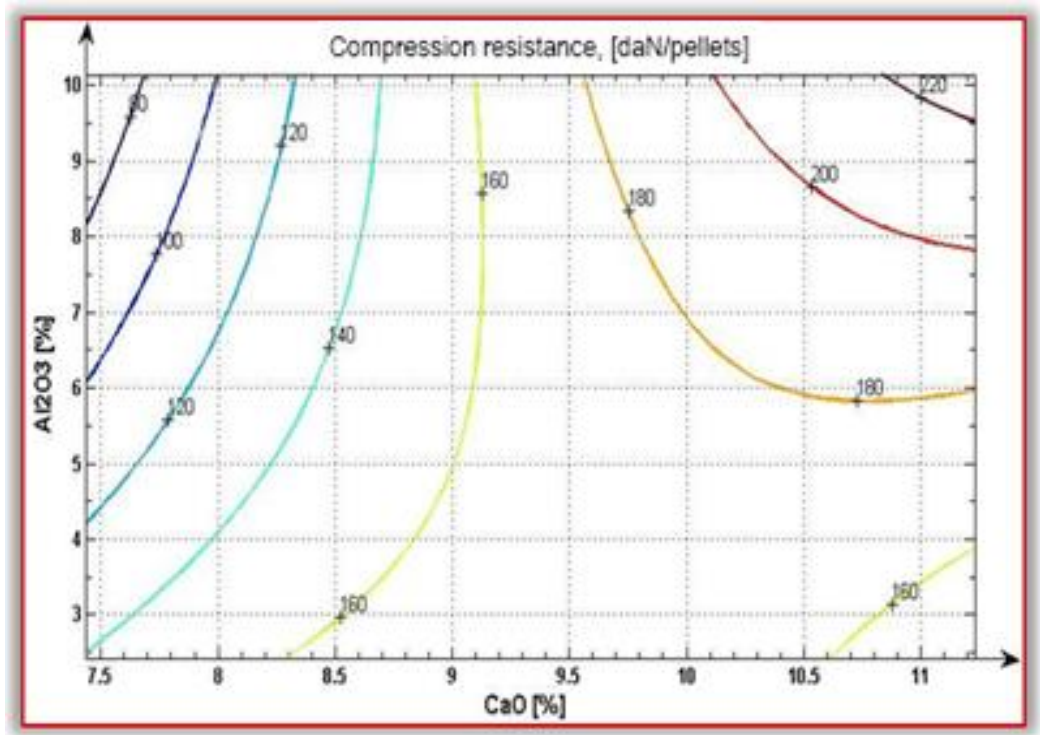

(b) horizontal projection level curves / correlation chart

Figure 12

Compression resistance of burned pellets according to the proportion of $\mathrm{Al}_{2} \mathrm{O}_{3}$ and $\mathrm{CaO}$ 


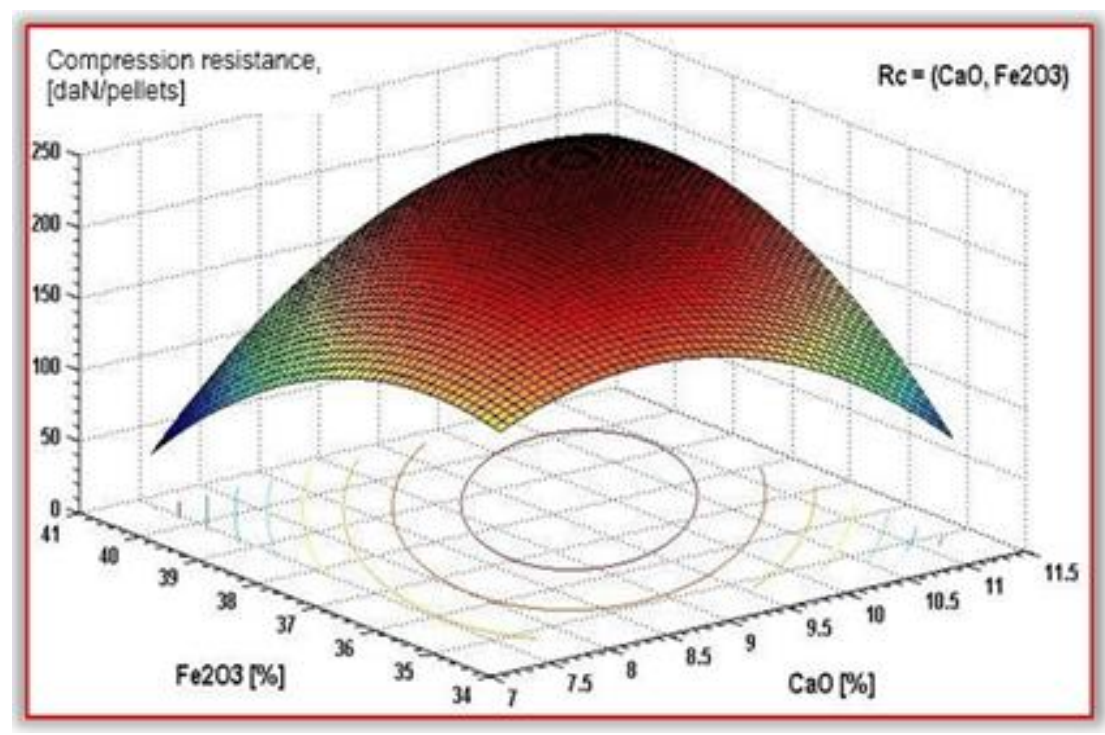

(a) spatial representation

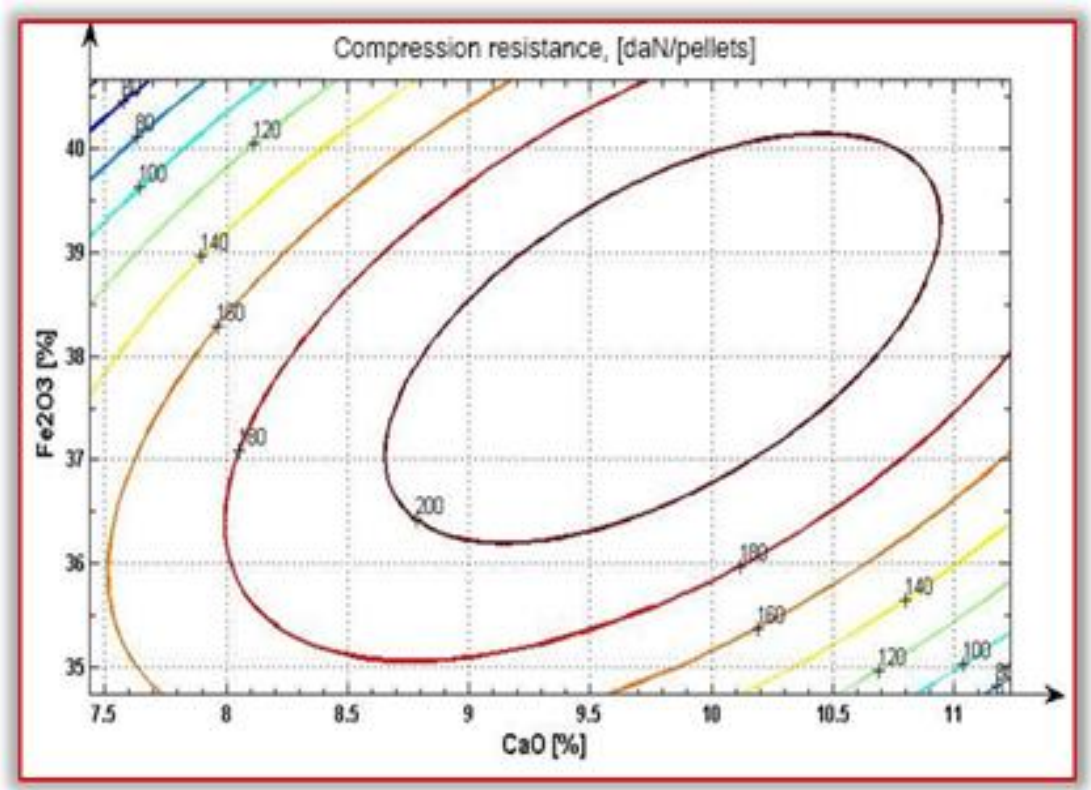

(b) horizontal projection level curves / correlation chart

Figure 13

Compression resistance of burned pellets according to the proportion of $\mathrm{Fe}_{2} \mathrm{O}_{3}$ and $\mathrm{CaO}$ 


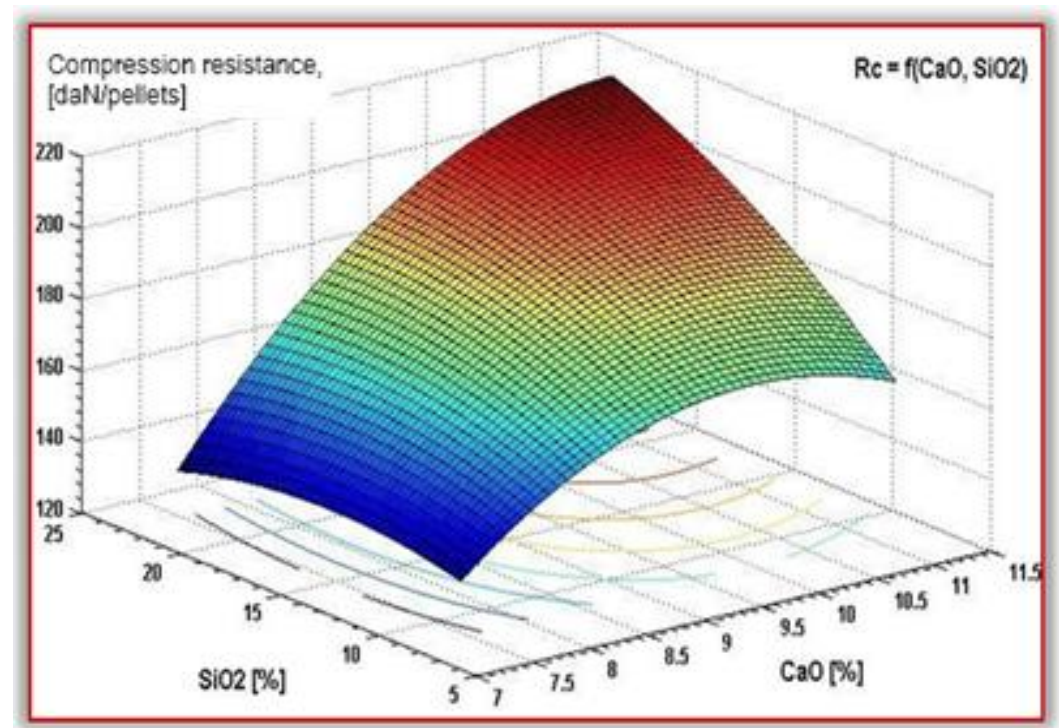

(a) spatial representation

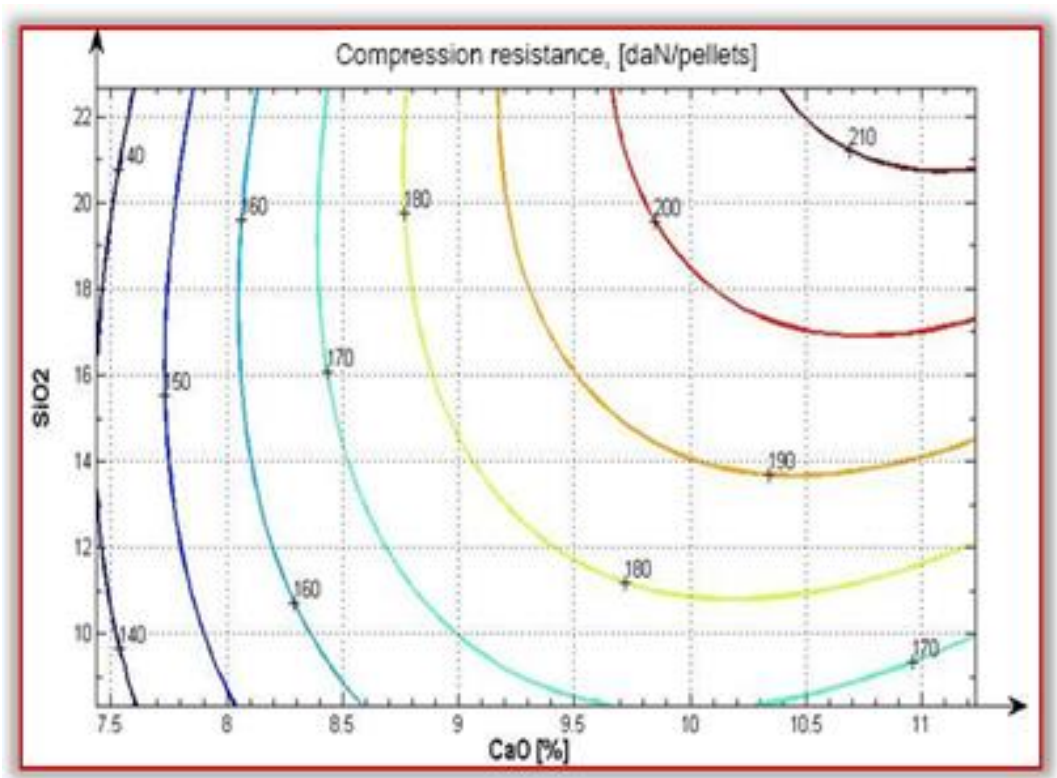

(b) horizontal projection level curves / correlation chart

Figure 14

Compression resistance of burned pellets according to the proportion of $\mathrm{SiO}_{2}$ and $\mathrm{CaO}$ 


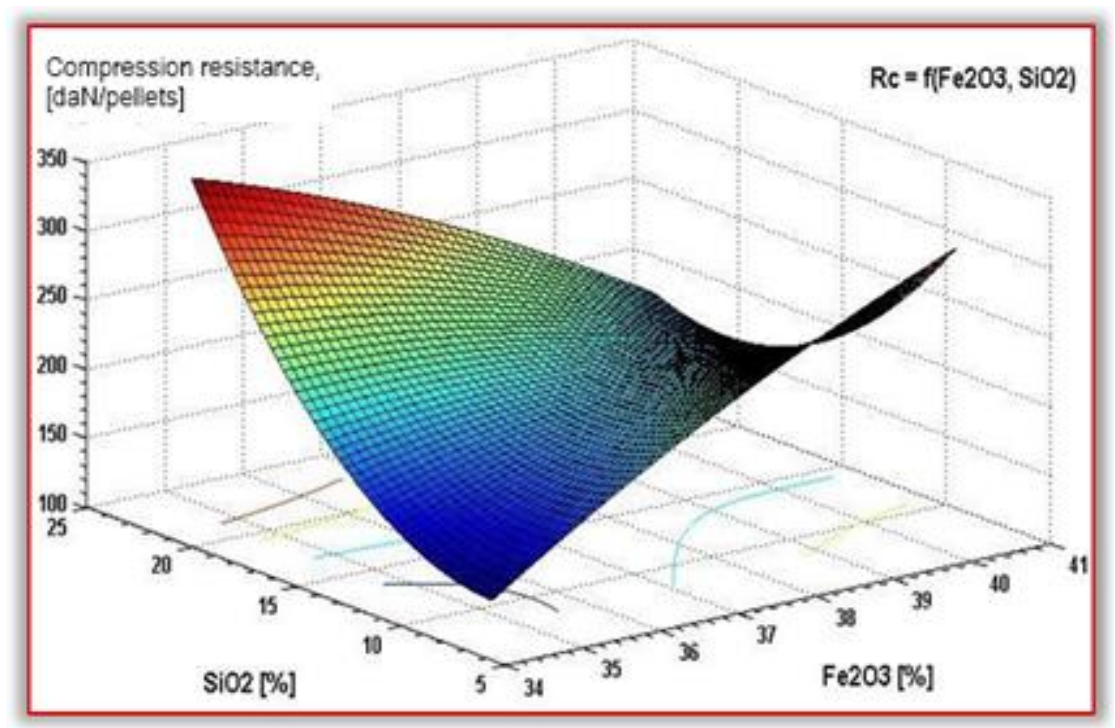

(a) spatial representation

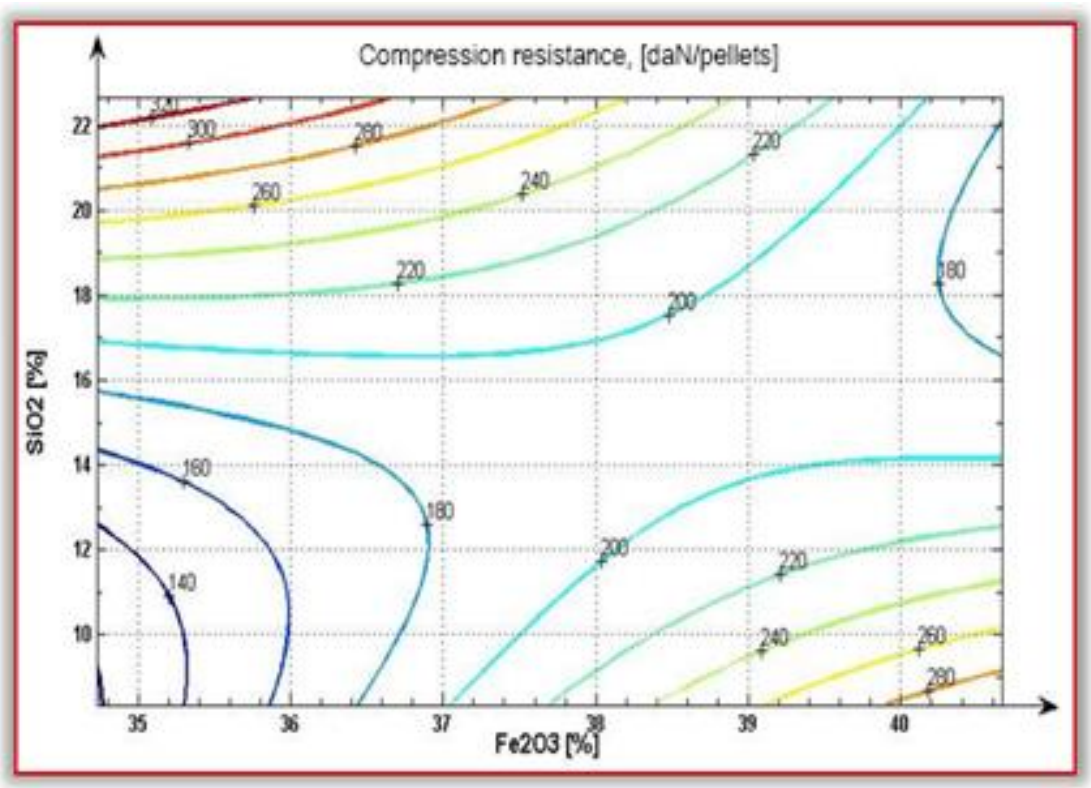

(b) horizontal projection level curves / correlation chart

Figure 15

Compression resistance of burned pellets according to the proportion of $\mathrm{Fe}_{2} \mathrm{O}_{3}$ and $\mathrm{SiO}_{2}$ 
Overall, correlated with the results presented in [24], the following technological remarks are required:

- The increase of the proportion of steelworks dust (with high intake of $\mathrm{Fe}_{2} \mathrm{O}_{3}$, over $70 \%$ ) has an influence on compression resistance, the best values being obtained between $30-60 \%$ steelworks dust. Technologically it is recommended to use this assortment in $20-75 \%$.

- The agglomeration-furnace dust, with an intake of about $40 \% \mathrm{Fe}_{2} \mathrm{O}_{3}$, can be used very well in pelleting recipes up to $60 \%$ if intended in electric arc furnaces. With the increase in addition, the resistance to compression decreases slightly due to the weaker wetting capacity of this assortment (contains carbon and different oxides in proportion of about $10 \%$, they act during the hardening of the pellets as reducers).

- Regarding the influence of red sludge (with significant input of $\mathrm{Fe}_{2} \mathrm{O}_{3}$ and $\mathrm{Al}_{2} \mathrm{O}_{3}$ and appreciably $\mathrm{CaO}$ and $\mathrm{SiO}_{2}$ ) the increase in its proportion leads to an increase in compression resistance, the technological explanation being that it has a high content of $\mathrm{Al}_{2} \mathrm{O}_{3}$ and $\mathrm{SiO}_{2}$, which also provides the role of binder. For this purpose, it can be used in a concentration of $10-12 \%$.

- Although compression resistance decreases with the increase in the proportion of sludge from anti-corrosive protection (they have low intake of $\mathrm{Fe}_{2} \mathrm{O}_{3}, \mathrm{SiO}_{2}$ and $\mathrm{Al}_{2} \mathrm{O}_{3}$ ), it can be used without restrictions up to about $12 \%$ in the pelletizing charges.

\section{Conclusions}

Currently, in Romania, the total area occupied by industrial landfills has been estimated at about 10300 ha and more than 12000 ha of land are affected by the storage of industrial waste, of which about $50 \%$, represent the areas occupied by waste dumps. In addition to the waste dumps, the largest areas of land are occupied by slag and ash dumps that are related to the metallurgical industry. There are numerous ponds or dumps of abandoned waste, slag or ash, which are, at the same time, areas of historical pollution and current pollution zones, storage being the most used method for the disposal of industrial waste in Romania. Theoretically these are temporary storage sites, until their use, recovery, recycling, treatment or final storage, but this temporary "storage" clearly takes several years, in some cases, essentially changing the storage area to an unprotected landfill. All these considerations lead to the conclusion that waste management requires the adoption of specific measures, appropriate to each waste disposal phase, the avoidance of overcrowding of controlled landfills (ponds or dumps) and the treatment of these types of waste, for economic purposes.

Industrial and mining waste still poses a challenge for many states where industrial and mining facilities have existed or still exist. Waste may be stored at the generation site before transfer to long-term storage, landfill or subsequent 
management (reuse, recovery, recycling, treatment or final disposal). However, these landfills may be:

- A threat to local communities when they are abandoned without measures to reduce the risk to the environment.

- An opportunity for local communities where spilled waste could generate activities involving the recovery of metals or other useful secondary raw materials.

The steel industry must identify all possible sources with iron content, within the production-use-recycling cycle and implement the most effective methods for retaining all these sources. Successful management determines the protection of natural iron resources, the recovery of those consumed and thus, can reduce the costs and impact of waste disposed of on the environment. Finding economically and environmentally efficient solutions for the technological flows in the steel industry, and includes the exploitation of useful elements from small size and powdery wastes existing landfilled areas.

Based on processes of reduction of oxide content materials, the technological solutions proposed in our research, are aimed at the valorization of secondary materials, consisting of powdery and small size waste, from the iron- and steel production industry and other mineral related processes. Based on the literature and our own experimental results, we believe that pelletization processes can be viable technological solutions, for the processing of this waste and a benefit to any related industries.

\section{Acknowledgment}

The study was carried out on the basis of extensive research over the last 20 years, undertaken within the Hunedoara Faculty of Engineering, following the results of numerous researches $[8,12-24]$ that concerned a large number of researchers in this institution. This research presented now is part of the research on the doctoral thesis [12], as well as, various research undertaken, after this period, in order to recover by the pelletization of materials containing valuable or worthwhile elements, from different kinds of powdery waste stored in areas involving risk factors.

\section{References}

[1] G. A. Blengini, F. Mathieux, L. Mancini, M. Nyberg, H. M. Viegas, Recovery of critical and other raw materials from mining waste and landfills - State of play on existing practices, Luxembourg: Publications Office of the European Union (2019)

[2] Ministry of Environment, Waters and Forests, Romania, National Strategy for the Management of Contaminated Sites (2015) http://www.mmediu.ro

[3] National Environmental Protection Agency, Present status for Soil Rehabilitation in Romania - Priorities, Workshop on Contaminated site 
caracterisation, $7^{\text {th }}$ Framework Programme Theme 6 "Environment", Soil and Subsoil Protection Office (2013)

[4] Romanian Government, National Strategy and National Plan for the management of contaminated sites in Romania. Chapter III: Current situation of potentially contaminated/contaminated sites in Romania (2013)

[5] R. J. Holmes, L. Lu, Iron Ore - Mineralogy, Processing and Environmental Sustainability, Chapter 1 - Introduction: overview of the global iron ore industry, Woodhead Publishing (2015) pp. 1-42

[6] D. Zhu, J. Pan, L. Lu, R. J. Holmes, Iron Ore - Mineralogy, Processing and Environmental Sustainability, Chapter 15 - Iron ore pelletization, Woodhead Publishing (2015) pp. 435-473

[7] D. Janke, L. Savov, M. E. Vogel, Secondary materials in steel production and recycling, Sustainable Metals Management. Eco-Efficiency in Industry and Science, 19, Springer (2006) pp. 313-334

[8] T. Heput, E. Ardelean, N. Constantin, A. Socalici, M. Ardelean, R. Buzduga, Recovery of small and powder ferrous waste, Politehnica Publishing House, Timisoara (2011) pp. 7-11

[9] H. W. Campbell, Sludge management-future issues and trends, Water science and technology, 41(8) (2000) pp. 1-8

[10] F. Su, H. O. Lampinen, R. Robinson, Recycling of sludge and dust to the BOF converter by cold bonded pelletizing, ISIJ international, 44(4) (2004) pp. $770-776$

[11] S. Kumar, R. Kumar, A. Bandopadhyay, Innovative methodologies for the utilisation of wastes from metallurgical and allied industries, Resources, Conservation and Recycling, 48(4) (2006) pp. 301-314

[12] S. Serban, Research on waste recovery containing iron and steel alloying elements, University Politehnica Timisoara (2015) doctoral thesis

[13] T. Heput, A. Socalici, E. Ardelean, M. Ardelean, Environment ecological process in Hunedoara area through reinsertion in economic circuit of scrap and pulverous waste. Annals of the Faculty of Engineering Hunedoara Journal of Engineering, VII(3) (2009) pp. 293-298

[14] T. Heput, I. Kiss, V. Puţan, Researches regarding the implementation in the industrial practices of the accounting technologies of the ferrous pulverous wastes, stored in the regional ponds, Annals of the Faculty of Engineering Hunedoara, 1(2) (2003) pp. 71-75

[15] S. Serban, T. Heput, I. Kiss, Recycling experiments on pulverous wastes resulted from ferrous industry, mining and energetic sectors, Acta Technica Corviniensis - Bulletin of Engineering, X, 2 (2017) pp. 139-146 
[16] S. Serban, T. Heput, Ferrous wastes recovery possibilities in the area of steel industry - experiments in the laboratory phase on the briquettes production from fine and pulverous wastes, Acta Technica Corviniensis Bulletin of Engineering, VIII, 3 (2015) pp. 49-56

[17] S. Serban, T. Heput, I. Kiss, Recovery possibilities through pelletizing of the pulverous wastes stored in the regional ponds, VIth International Conference Industrial Engineering \& Environmental Protection (IIZS 2016) Zrenjanin, Serbia, 2016, pp. 116-121

[18] S. Serban, Reintroduction of iron-containing waste and steel alloying elements into the economic circuit, Acta Technica Corviniensis - Bulletin of Engineering, XI, 4 (2018) pp. 127-134

[19] M. L. Strugariu, T. Heput, A. Socalici, Recovery of sludge resulting from corrosion protection operations, Metalurgia International, 18(8) (2013) pp. $161-166$

[20] A. V. Socalici, E. Ardelean, M.L. Strugariu, Research on sustainable use of powdery waste, Environmental Engineering and Management Journal, 15(1) (2016) pp. 207-212

[21] D. A. Popescu, Study on the quality of industrial waste deposited in ponds, Annals of Faculty of Engineering Hunedoara - International Journal of Engineering, XII, 4 (2014) pp. 315-321

[22] A. S. Todorut, Management research and recovery of small and powdery wastes, resulted from materials industry, for sustainable development of Hunedoara, University Politehnica Timisoara (2013) doctoral thesis

[23] E. M. Crisan, T. Heput, Research on the influence of basic additives on the compressive strength of pellets. Annals of Faculty of Engineering Hunedoara - International Journal of Engineering, 9(3) (2011) pp. 449454

[24] S. Serban, I. Kiss, Identifying possibilities for superior recovery by pelletization of industry related small and powdery iron containing waste, Acta Polytehnica Hungarica (2021) [in press] 